\title{
HUMAN CAPITAL DAN KINERJA KARYAWAN (Suatu Tinjauan Teoritis)
}

\author{
Oleh \\ Yuni Kasmawati \\ Dosen Fakultas Teknolologi Informasi \\ Universitas Budi Luhur \\ Email: \\ yuni.kasmawati@budiluhur.ac.id
}

\begin{abstract}
ABSTRAK
Pergeseran paradigma tentang modal dasar sebuah organisasi pada dekade saat ini mengalami lompatan. Modal manusia memiliki peran sentral dalam kesuksesan sebuah organisasi. Paper ini memberikan tinjauan literatur yang memfokuskan hubungan antara human capital dan kinerja karyawan. Penerapan tinjauan literatur yang ada memungkinkan untuk mengungkap dua masalah utama yaitu 1). Menganalisis hubungan human capital dengan kinerja karyawan 2).Manajemen modal manusia. Semakin banyak penelitian telah mencoba untuk menunjukkan hubungan antara sumber daya manusia dan kinerja karyawan.
\end{abstract}

Kata Kunci : Human Capital, Manajemen Modal Manusia, Kinerja Karyawan

\section{A. PENDAHULUAN}

Perubahan yang disebabkan oleh globalisasi industri, kemajuan informasi, perkembangan teknologi dan persaingan yang ketat, menyebabkan berbagai perusahaan mengubah strategi dalam menjalankan bisnisnya.

Isu yang berkepanjangan, dimana beberapa penulis menyatakan bahwa manajemen dan sistem pelaporan yang telah mapan selama ini secara berkelanjutan kehilangan relevansinya karena tidak mampu menyajikan informasi yang esensial bagi eksekutif untuk mengelola proses yang berbasis pengetahuan (knowledge-based processes) dan intangible resources (Bornemann dan Leitner, 2002).

Istilah human capital untuk sumber daya manusia (SDM) belum banyak dianut oleh pelaku bisnis, sementara peran SDM terhadap masa depan perusahaan sangat menentukan. Apapun bentuk serta tujuannya, organisasi dibentuk berdasarkan visi untuk kepentingan manusia dan dalam pelaksanaan misinya dikelola dan diurus oleh manusia. Jadi manusia merupakan faktor strategis dalam semua kegiatan organisasi. Untuk itu menangani SDM yang handal harus dilakukan sebagai human capital. Morling dan Yakhlef (1999) menyatakan bahwa yang akan menentukan kesuksesan perusahaan adalah kemampuan perusahaan dalam mengelola aset pengetahuan. Mengacu pada perkembangan yang terjadi saat ini, menuntut perusahaan-perusahaan dapat bersaing dengan menggunakan 
keunggulan kompetitif yang diperoleh melalui inovasi-inovasi kreatif yang dihasilkan oleh modal intelektual yang dimilikinya.

SDM adalah capital yang dapat terus berkembang seiring dengan waktu dan dinamika lingkungan bisnis serta kemajuan dalam ilmu pengetahuan. Keunggulan SDM dibandingkan faktor produksi lainnya dalam strategi persaingan suatu perusahaan antara lain: kemampuan inovasi dan entrepreneurship, kualitas yang unik, keahliaan yang khusus, pelayanan yang berbeda dan kemampuan produktivitas yang dapat dikembangkan sesuai kebutuhan. (Mathis, 2003). Perhatian terhadap sumber daya manusia atau human capital sebagai salah faktor produksi utama bagi kebanyakan perusahaan sering dinomorduakan dibandingkan dengan faktor-faktor produksi yang lain seperti modal, teknologi, dan uang. Banyak pemimpin perusahaan kurang menyadari bahwa sebenarnya keuntungan yang diperoleh perusahaan berasal dari human capital. Hal ini disebabkan karena aktivitas perusahaan hanya dilihat dari perspektif bisnis semata. Para pemimpin perusahaan tidak melihat perusahaan sebagai sebuah unit pengetahuan dan keterampilan yang unik, atau seperangkat keunikan dari aset usahanya yang dapat membedakan produk atau jasa dari para pesaingnya.

Penilaian kinerja perusahaan berbasis human capital merupakan hal menarik yang perlu dikembangkan oleh perusahaan. Human capital adalah salah satu komponen utama dari intellectual capital (intangible asset) yang dimiliki perusahaan. Selama ini, penilaian terhadap kinerja perusahaan lebih banyak menggunakan sumber daya yang bersifat fisik (tangible asset). Menurut Mayo (2000) mengukur kinerja perusahaaan dari perspektif keuangan sangatlah akurat tetapi sebenarnya yang akan menjadi dasar penggerak nilai dari keuangan tersebut adalah sumber daya manusia (human capital) dengan segala pengetahuan, ide dan inovasi yang dimilikinya. Penilaian atau pengukuran kinerja merupakan salah satu faktor yang penting dalam perusahaan. Selain digunakan untuk menilai keberhasilan perusahaan, pengukuran kinerja juga dapat digunakan sebagai dasar untuk menentukan sistem imbalan dalam perusahaan. Pihak manajemen juga dapat menggunakan pengukuran kinerja perusahaan sebagai alat untuk mengevaluasi pada periode sebelumnya. Penelitian ini bertujuan untuk melakukan tinjauan ringkas secara teoritis terhadap peran SDM atau human capital dalam meningkatkan kinerja karyawan.

\section{B. KAJIAN PUSTAKA}

\section{Kinerja}

Menurut Rivai (2005), kinerja merupakan prestasi yang dicapai oleh seseorang dalam melaksanakan pekerjaannya sesuai standar dan kriteria yang ditetapkan untuk pekerjaan itu. Kinerja dalam menjalankan fungsinya tidak berdiri sendiri, tapi berhubungan dengan kepuasan kerja dan tingkat imbalan, dipengaruhi oleh ketrampilan, kemampuan dan sifat-siafat individu. (Rivai, 2005:16). Jika penilaian kinerja (performance appraisal), dikerjakan dengan benar, akan memberi manfaat yang penting bagi karyawan, supervisor, departemen SDM dan perusahaan (Rivai, 2005).

Performance diterjemahkan menjadi kinerja, juga berarti prestasi kerja atau 
pelaksanaan kerja atau pencapaian kerja atau hasil kerja/ unjuk kerja/ penampilan kerja (LAN, 1992). Menurut Gibson, Ivancevich dan Donnelly (1997) bahwa kinerja adalah tingkat keberhasilan dalam melaksanakan tugas dan kemampuan untuk mencapai tujuan yang telah ditetapkan. Dikaitkan dengan peran individu dalam organisasi, kinerja adalah serangkaian perilaku atau kegiatan individu yang sesuai dengan harapan atau keinginan organisasi tempat ia bekerja (Arnold dan Feldman, 1986). Menurut Steers dan Porter (1987) bahwa kinerja (performansi) dipengaruhi oleh motif-motif individu dalam berinteraksi dengan lingkungannya. Berdasarkan pernyataan tersebut, dapat dinyatakan kinerja adalah sebagai ekspressi potensi berupa perilaku atau cara seseorang orang dalam melaksanakan suatu kegiatan atau tugas sehingga menghasilkan suatu produk yang merupakan wujud dari semua tugas dan tanggungjawab pekerjaan yang diberikan kepadanya.

Menurut Schuler dan Jackson (1999) kriteria kinerja yang dinilai adalah meliputi hal-hal berikut :

1. Kriteria berdasarkan sifat yaitu kriteria yang memusatkan pada karakteristik pribadi seorang karyawan.

2. Kriteria berdasarkan perilaku yaitu kriteria yang memusatkan pada bagaimana pekerjaan dilaksanakan.

3. Kriteria berdasarkan hasil yaitu kriteria yang berfokus pada hasil yang dicapai ketimbang bagaimana pekerjaan itu dihasilkan

Menurut Rivai (2004), tujuan penilaian kinerja karyawan antara lain : untuk mengetahui tingkat prestasi karyawan, pemberian imbalan yang sesuai, mendorong pertanggungjawaban dari karyawan, pembeda antara karyawan yang satu dengan yang lainnya, pengembangan SDM, meningkatkan motivasi, meningkatkan etos kerja, sebagai salah satu sumber informasi perencanaan SDM, serta membantu menempatkan karyawan dengan pekerjaan yang sesuai untuk mencapai hasil baik secara menyeluruh. Manfaat penilaian kinerja bisa dilihat dari berbagai pihak, yaitu pihak orang yang dinilai, penilai (atasan, supervisor, pimpinan, manager, konsultan) dan pihak perusahaan.

Kinerja dalam menjalankan fungsinya tidak berdiri sendiri, tapi berhubungan dengan kepuasan kerja dan tingkat imbalan, yang dipengaruhi oleh ketrampilan, kemampuan dan sifat-sifat individu (Rivai, 2005). Sedang menurut Simanjuntak (2005) kinerja karyawan dalam menjalankan tugas dan tanggung jawabnya dipengaruhi oleh kompetensi individu, dukungan organisasi dan dukungan manajemen.

Banyak faktor yang mempengaruhi kinerja pegawai baik publik maupun swasta. Secara detail Ruky dalam Tangkilisan (2005) mengidentifikasikan faktorfaktor yang berpengaruh langsung terhadap tingkat pencapaian kinerja pegawai sebagai berikut :

1. Teknologi yang meliputi peralatan kerja dan metode kerja yang digunakan untuk menghasilkan produk dan jasa yang dihasilkan oleh organisasi, semakin berkualitas teknologi yang digunakan, maka akan semakin tinggi kinerja individu tersebut;

2. Kualitas input atau material yang digunakan oleh individu;

3. Kualitas lingkungan fisik yang meliputi keselamatan kerja,

4. Penataan ruangan, dan kebersihan; 
5. Budaya organisasi sebagai pola

6. tingkah laku dan pola kerja yang ada dalam organisasi yang bersangkutan;

7. Kepemimpinan sebagai upaya untuk mengendalikan anggota organisasi agar bekerja sesuai dengan standar dan tujuan organisasi;

8. Pengelolaan sumber daya manusia yang meliputi aspek kompensasi, imbalan, promosi, dan lain-lainnya.

Unsur-unsur yang dinilai dalam penilaian kinerja (Hasibuan, 2005) yaitu :

1. Kesetiaan, dicerminkan oleh kesediaan karyawan menjaga dan membela organisasi di dalam maupun di luar pekerjaan.

2. Prestasi kerja, dinilai dari hasil kerja baik kuantitas maupun kualitas yang dapat dihasilkan karyawan tersebut dari uraian pekerjaannya.

3. Kejujuran. Kejujuran dalam memenuhi perjanjian baik bagi dirinya sendiri maupun terhadap orang lain.

4. Kedisiplinan. Kedisiplin karyawan dalam mematuhi peraturan-peraturan yang ada dan melakukan pekerjaannya sesuai dengan instruksi.

5. Kreativitas. Kemampuan karyawan dalam mengembangkan kreativitasnya untuk menyelesaikan pekerjaannya.

6. Kerja sama. Kesediaan karyawan berpartisipasi dan bekerja sama dengan karyawan lainnya secara vertikal atau horisontal.

7. Kepemimpinan. Kemampuan untuk memimpin, berpengaruh, pribadi yang kuat, dihormati, berwibawa dan dapat memotivasi orang lain.

8. Kepribadian. Sikap perilaku, kesopanan, memberi kesan menyenangkan, memperlihatkan sikap yang baik, serta berpenampilan simpatik dan wajar.

9. Prakarsa. Kemampuan berpikir yang orisinil dan berdasarkan inisiatif sendiri untuk menganalisis, menilai, menciptakan, memberikan alasan, mendapatkan kesimpulan, dan membuat keputusan penyelesaian masalah yang dihadapinya.

10. Kecapakan. Kecakapan karyawan dalam menyatukan dan menyelaraskan bermacam-macam elemen.

11. Tanggung jawab. Pertanggungjawaban kebijaksanaan, pekerjaan dan hasil kerja, sarana dan prasarana yang dipergunakannya serta perilaku kerjanya.

Hasil studi Lazer dan Wikstrom terhadap formulir penilaian kinerja 125 perusahaan, bahwa aspek - aspek yang dinilai tersebut dikelompokkan menjadi : kemampuan teknis, kemampuan konseptual, kemampuan hubungan interpersonal (Rivai, 2004).

\section{Human Capital}

Menurut Wealtherly (2003), nilai perusahaan didasarkan atas tiga kelompok utama aset, yaitu:

1. Financial asset, seperti kas surat-surat berharga yang sering disebut juga dengan financial capital

2. Physical asset, terdiri atas peralatan, gedung, tanah, disebut juga dengan tangible asset.

3. Intangible asset, yaitu organizational capital, seperti aliansi bisnis, customer capital, merek, reputasi kualitas dan pelayanan; dan intellectual capital (paten, desain produk, dan teknologi), goodwill, dan human capital. 
Wright et al (2001) menyatakan bahwa intellectual capital adalah faktor yang terdiri dari human capital, social capital and organizational capital. Sementara Nahapiet dan Ghoshal (1998), intellectual capital berkaitan dengan "knowledge and knowing capability of a social collectivity", sebagai suatu organisasi, komunitas intelektual, atau praktek profesional. Edvinson, Stewart, dan Sueby (dalam Burr dan Girardi, 2002) mengkategorikan Intellectual Capital terdiri dari dua elemen, yaitu human capital dan structural capital. Namun, yang terpenting adalah human capital karena aset inilah yang menentukan kesuksesan perusahaan dalam persaingan.

OECD (1999) mendefinisikan intellectual capital sebagai nilai ekonomi dari dua kategori intangible assets perusahaan, yaitu organizational and human capital. Menurut Schermerhon (2005), human capital dapat diartikan sebagai nilai ekonomi dari SDM yang terkait dengan kemampuan, pengetahuan, ide-ide, inovasi, energi dan komitmennya. Human capital merupakan kombinasi dari pengetahuan, ketrampilan, inovasi dan kemampuan seseorang untuk menjalankan tugasnya sehingga dapat menciptakan suatu nilai untuk mencapai tujuan. Pembentukan nilai tambah yang dikontribusikan oleh human capital dalam menjalankan tugas dan pekerjaannya akan memberikan sustainable revenue di masa akan datang bagi suatu organisasi (Malhotra dan Bontis dalam Rachmawati dan Wulani, 2004).

Teori modal manusia menekankan bagaimana pendidikan dapat meningkatkan produktivitas dan efisiensi pekerja dengan meningkatkan tingkat saham kognitif atas ekonomi produktif dari kemampuan manusia yang merupakan hasil dari investasi pada manusia (Olaniyan dan Okemakinde, 2008). Schultz (1961) telah mendefinisikan teori modal manusia sebagai pengetahuan dan keterampilan yang diperoleh oleh orang-orang sebagai modal dalam pendidikan keterampilan maupun teknis. Modal tersebut merupakan produk investasi yang dianggap baik dan menghasilkan pendapatan (Fitzsimmons, 1999 dalam Zula dan Chermack, 2007).

Menurut Stewart et al dalam Sawarjuwono dan Kadir (2003) mengatakan bahwa human capital merupakan lifeblood dalam intellectual capital, sumber dari innovation dan improvement, tetapi merupakan komponen yang sulit untuk diukur. Human capital mencerminkan kemampuan kolektif perusahaan untuk menghasilkan solusi terbaik berdasarkan pengetahuan yang dimiliki oleh orangorang yang ada dalam perusahaan tersebut, dimana akan meningkat jika perusahaan mampu menggunakan pengetahuan yang dimiliki oleh karyawannya.

\section{Komponen Human Capital}

Setiap komponen memiliki peranan yang berbeda dalam menciptakan human capital perusahaan yang akan menentukan nilai sebuah perusahaan. Oleh karena itu, mengingat peran SDM yang begitu besar dalam perusahaan, maka, manajemen perusahaan harus lebih proaktif menjadikan SDM-nya sebagai human capital yang perlu diberi perhatian dan pengembangan secara terus menerus sesuai dengan kedinamisan lingkungan bisnis (Mayo, 2000). Berikut adalah komponen human capital dari beberapa pendapat. 


\begin{tabular}{ccl}
\hline NO. & OUTHOR & \multicolumn{1}{c}{ KOMPONEN HUMAN CAPITAL } \\
\hline 1. & Yang dan Lin (2009) & $\begin{array}{l}\text { Human capital merupakan asset inti dalam } \\
\text { sebuah organisasi, mencakup pengetahuan, } \\
\text { kecakapan, pengalaman, kompetensi, sikap, }\end{array}$ \\
& & $\begin{array}{l}\text { komitmen, dan karakteristik pribadi individual. } \\
\text { daman capital sebagai kombinasi kombinasi }\end{array}$ \\
2. Jac Fitz-Enz (2009) & komitmen tenaga kerja
\end{tabular}

3. Davemport (1999:18) Human capital terdiri atas : kemampuan, perilaku, usaha, dan waktu, yang dimiliki dan dikendalikan sendiri oleh karyawan.

4. Mayo (2000:120) Human capital memiliki lima komponen yaitu individual capability, individual motivation, leadership, the organizational climate, dan workgroup effectiveness.

5. Ross, Dragonetti, dan Human capital merupakan pengelompokan tiga Edvinsson 2005 elemen kunci, yaitu kecakapan, sikap, dan kecerdasan intelektual

6. Sharabati et al. 2010 Human capital terdiri dari innovation dan creation, learning dan education, and experience dan expertise

7. Ployhart Moliterno (2011)

dan Konsep human capital merupakan sumber daya yang muncul dari knowledge, skills, abilities, and other characteristics (KSAOs) sebagai individu karyawan.

8. Wright dan Moliterno Human capital terdiri dari dimensi dan (2013) karakteristik yaitu ability, personality, skill, knowledge, affect dan behavior.

9. Bontis dan Serenko Modal manusia meliputi tiga faktor, yaitu (2009) kompetensi, pengalaman dan pengetahuan

10. Hitt, Bieman, Shimizu Penielitiannya mencatat bahwa modal manusia dan Kochhar (2001)

11. Wright, McMahan dan McWilliams (1994)

12. Edvinsson dan Malone (1977)

13. Ancok (2008) memiliki dua dimensi, yaitu kualitas dan pengalaman.

Modal manusia melibatkan dimensi pengalaman, penilaian dan kecerdasan.

Human capital (SDM strategik) merupakan kombinasi pengetahuan, keterampilan, keinovasian, dan kemampuan karyawan untuk melaksanakan tugas-tugasnya termasuk nilainilai perusahaan, kultur dan filosofi

Ada 7 komponen modal manusi yaitu modal intelektual, modal emosional, modal sosial, modal ketabahan, modal moral, modal kesehatan 


\section{Peran Human Capital}

Merujuk Fitz-enz (2000), mengakhiri abad 20, para pengelola organisasi telah menerima bahwa faktor manusia-lah dan bukannya uang, bangunan, dan peralatan, yang merupakan faktor pembeda kinerja. Apalagi ketika saat ini kita memasuki masyarakat atau perekonomian berbasis pengetahuan, peran modal manusia dan komponen modal intelektual lainnya menjadi sangat critical.

Kontribusi modal manusia dapat dianalisis dari dua perspektif yaitu secara mikro dan makro. Sudut pandang mikro memandang bahwa modal manusia merupakan bagian dari fungsi produksi pada individu yang selanjutnya berkaitan dengan kualitas dari sumber daya manusia. Pengetahuan dapat memberikan dampak terhadap penguasaan teknologi dan adanya inovasi yang dilakukan dalam hal proses produksi. Hasil dari adanya pengetahuan tersebut adalah adanya efisiensi dalam proses produksi yang berpotensi pada peningkatan produktivitas. Di sisi lain adanya keahlian akan menjadikan individu menjadi lebih kompeten dalam proses produksi sehingga mendorong produktivitas.

Peranan modal intelektual sangat berpengaruh terhadap kinerja karyawan dan dalam jangka panjang akan mempengaruhi kinerja organisasi, karena modal intelektual dapat digunakan organisasi untuk menciptakan kinerja yang diharapkan, dan sebagai alat evaluasi kinerja karyawan untuk menciptakan karyawan yang survive terhadap kebutuhan organisasi ke depan. Modal intelektual merupakan potensi di masa depan yang merupakan kombinasi dari modal manusia dan potensi dari orang-orang dalam organisasi. Dengan demikian, modal intelektual merupakan aset yang tidak terlihat yang merupakan gabungan dari faktor manusia, proses dan pelanggan yang memberikan keunggulan kompetitif.

Son (2010) dalam Sanerya Hendrawan et.al (2012) menyatakan bahwa human capital berperan penting dalam pertumbuhan ekonomi dan pengentasan kemiskinan. Secara makro, akumulasi human capital meningkatkan produktivitas tenaga kerja, memfasilitasi inovasi teknologi, meningkatkan returns to capital, menciptakan pertumbuhan berkesinambungan, dan pada gilirannya mendukung pengentasan kemiskinan. Secara mikro, human capital yang dibangun melalui pendidikan berpotensi meningkatkan kemungkinan seseorang mendapatkan pekerjaan di pasar tenaga kerja dan meningkatkan kapasitas memperoleh penghasilan yang lebih besar.

Human capital tentunya perlu dikelola sehingga organisasi benar-benar dapat menggunakan asset yang berharga tersebut. Human capital management berkaitan dengan mendapatkan, menganalisis, dan melaporkan nilai tambah dari modal intelektual, serta pengelolaan human capital dengan menganggap mereka sebagai asset dan menekankan bahwa keunggulan kompetitif dicapai dengan investasi strategis dalam asset melalui keterlibatan karyawan, manajemen bakat, pembelajaran dan pengembangan program (Amstrong, 2012).

Peran human capital dalam penciptaan kekayaan intelektual (intellectual assets) sangat strategis, karena hanya human capital (SDM) yang dapat menciptakan pengetahuan dan sekaligus memiliki pengetahuan. Sedangkan pengetahuan itu sendiri merupakan unsur terpenting dalam proses penciptaan nilai organisasi/perusahaan, sehingga penciptaan nilai perusahaan sangat dipengaruhi 
oleh modal manusia (SDM strategik). Pendapat tersebut senada dengan pandangan Edvinsson dan Malone (1977) yang menyatakan bahwa human capital (SDM strategik) merupakan kombinasi pengetahuan, keterampilan, keinovasian, dan kemampuan karyawan untuk melaksanakan tugas-tugasnya termasuk nilainilai perusahaan, kultur dan filosofi.

Human capital adalah unsur yang sangat penting dari modal intelektual, karena dapat menciptakan daya saing bagi organisasi/perusahaan. Karena human capital merupakan kemampuan yang dimiliki setiap anggota organisasi untuk digunakan dalam proses penciptaan aset intelektual (Sangkala., 2006). Karenanya, human capital memiliki peran sangat urgen sebagai komponen kunci yang mempengaruhi tinggi-rendahnya tingkat kinerja sebuah organisasi/perusahaan. Pernyataan serupa dikemukakan oleh Ancok (2008) bahwa manusia dengan segala kemampuannya bila dikerahkan keseluruhannya akan menghasilkan kinerja yang luar biasa. Kemampuan tersebut sangat penting dalam proses inovasi.

Human capital memiliki daya dorong yang kuat guna perbaikan produktivitas individual karyawan, sekaligus meningkatkan kinerja perusahaan melalui kemampuan sumber daya manusia (SDM) mengkomunikasikan pengetahuan (soft skills), terampil dan profesional dalam bekerja dan mampu membangun nilai relasional berkesinambungan dalam bentuk kemitraan antara perusahaan sebagai stakeholder internal dan pelanggan sebagai stakeholder eksternal (Usup R. C., 2011).

Ulrich (1997) menjelaskan empat peran human capital dalam membangun organisasi yang kuat, diantaranya :

1. Management of Strategic human resources. Strategi ini membahas tentang proses masa depan

2. Management of Transformation and Change. Kegiatan utamanya adalah membawa organisasi ke arah yang lebih produktif dengan tingkat keuntungan yang tumbuh secara berkesinambungan.

3. Management of Firm Infrastructure. Kegiatan pokoknya adalah melakukan suatu rekayasa ulang untuk menuju ke arah perbaikan organisasi

4. Management of Employee Contribution, merupakan suatu usaha untuk meningkatkan loyalitas kemampuan karyawan.

\section{Hubungan Human Capital dengan Kinerja Karyawan}

Modal manusia merupakan nilai total sumber daya manusia dari suatu organisasi (Mantis \& Jackso, 1999). Nilai total sumberdaya manusia tersebut melibatkan semua staf dalam organisasi dan kemampuan mereka untuk menyelesaikan pekerjaan mereka sehingga berhasil (Wang \& Shieh, 2008). Modal manusia terdapat di dalam diri manusia karyawan, kontribusi karyawan penting dalam menentukan keberhasilan organisasi (Follis, 2001). Bahkan modal manusia tersebut yang menjadikan pekerja sebagai satu sumber daya yang unik untuk organisasi. Keunikan tersebut telah menjadikan modal manusia sebagai sumber efisiensi dan efektivitas organisasi, dan dianggap juga sebagai sumber daya strategis organisasi (Carmeli \& Tishler, 2004) . Sumber daya strategis mampu menghasilkan keunggulan kompetitif untuk organisasi (Bechtel, 2007) yang akhirnya dapat digunakan untuk bersaing dalam industri 
Menurut Totanan (2004) sebuah perusahaan akan menghasilkan kinerja yang berbeda jika dikelola oleh orang yang berbeda, oleh karena itu, SDM yang berbeda dalam mengelola aset perusahaan yang sama akan menghasilkan nilai tambah yang berbeda pula. Dapat disimpulkan bahwa tangible aset yang dimiliki perusahaan bersifat pasif tanpa sumber daya manusia yang dapat mengelola dan menciptakan nilai bagi suatu perusahaan. Beberapa penelitian terakhir telah membuktikan keterkaitan antara kinerja karyawan dengan proses pengelolaan SDM di perusahaan.

Penelitian terhadap seluruh pemimpin jurusan atau program studi (Ketua Jurusan, Sekretaris Jurusan dan Ketua Program Studi) dilakukan oleh Sukarman Purba (2009) mengenai pengaruh pengaruh budaya organisasi, modal intelektual,dan perilaku inovatif terhadap kinerja pemimpin jurusan di Universitas Negeri Medan menunjukkan bahwa modal intelektual yang berfokus pada modal manusia dengan dimensi kompetensi dan komitmen mempunyai pengaruh signifikan terhadap kinerja pimpinan jurusan.

Hasil penelitian yang dilakukan oleh Dian Swastari (2013) di PT. Telkomsel branch Purwokerto untuk menguji penerapan human capital management terhadap kinerja karyawan menyimpulkan bahwa kompetensi, individual capability dan individual motivation secara parsial memberi pengaruh yang signifikan terhadap kinerja karyawan. Secara bersama sama memberi pengaruh yang signifikan terhadap kinerja karyawan. Human capital mempunyai korelasi sangat signifikan terhadap kinerja karyawan.

Penelitian pengaruh human capital terhadap kinerja pada karyawan unit simpan pinjam koperasi serba usaha (KSU) Mekar Surya Karanganyar tahun 2016 yang dilakukan oleh Doddy Wahyu Triatmaja menunjukkan dimensi Human Capital (tingkat pendidkan, ketrampilan dan pengalaman kerja) baik secara bersama-sama maupun parsial berpengaruh positif dan signifikan terhadap kinerja pada karyawan. Disimpulkan juga bahwa pengalaman kerja adalah variabel yang paling dominan dalam mempengaruhi kinerja karyawan.

Human capital memberi pengaruh positif dan signifikan terhadap kinerja karyawan ditunjukkan oleh penelitian yang telah dilakukan oleh Eka Mulya Prasetya et al (2016) pada karyawan PT PLN (Persero) Unit Induk Pembangunan VIII Surabaya.

Modal manusia dengan dimensi akuntabilitas kerja, kompetensi, kepemilikan profesionel, komitmen karyawan untuk mengetahui peningkatan kinerja karyawan melalui Human capital dan Komitmen Karyawan yang diteliti oleh Fuji Utama memberi hasil bahwa terdapat hubungan positif dan signifiakan antara modal manusia dengan kinerja karyawan pada PT. Aspex Kumbong Bogor.

Husen Sutisna et al (2014) meneliti peran human capital, corporate value dan good corporate governance melalui kinerja karyawan terhadap Kinerja Perusahaan di PTPN VII Lampung menyimpulkan bahwa human capital mempunyai pengaruh nyata terhadap kinerja karyawan. Adapun dimensi Human Capital yang digunakan yaitu Knowledge, Skills, Abilities, Other characteristics, Learning education, Innovation creation, Experience dan expertise, Leadership. Dalam penelitiannya dijelaskan bahwa prioritas utama human capital adalah peningktan abilities 
Penelitian yang dilakukan oleh Peter Rex Massingham, Leona Tam, (2015) untuk mengetahui hubungan antara human capital dengan penghargaan karyawan (pay) menunjukkan bahwa human capital dengan dimensi employee capability, employee satisfaction, employee commitment menunjukkan bahwa employee capability berpengaruh positif signifikan terhadap penghargaan karyawan (pay). Hal ini berarti semakin tinggi kapabilitas karyawan, maka penghargaan terhadap akan meningkat akibat kinerja karyawan meningkat.

\section{HASIL DAN PEMBAHASAN}

Merujuk pada penelitian sebelumnya yang menyimpulkan bahwa human capital mempunyai pengaruh positif dan signifikan terhadap kinerja karyawan, maka suatu organisasi perlu mengelola human capital agar organisasi tersebut mampu bersaing dan mencapai keunggulan kompetitif. Dinyatakan oleh Fitz-enz (2000) bahwa nilai kontribusi modal intelektual yang makin signifikan, maka diperlukan pengelolaan untuk pertumbuhan (organisasi, ekonomi).

Konsep dari pengelolaan mengambarkan individu menghasilkan, menyimpan, menggunakan pengetahuan dan keterampilan sebagai modal intelektual, kemudian pengetahuan individu mereka satu sama lain diinteraksikan, dan mengahsilkan pengetahuan terlembagakan yang dimiliki oleh organisasi. Usaha-usaha yang dilakukan untuk mengelola human capital antara lain melalui :

1. Memprioritaskan dalam peningkatan produktivitas knowledge and service work untuk kemajuan organisasi (wibowo, 2012). Hal ini dikarenakan era asset tangible telah berakhir, penumpukan modal finansial, penambahan lahan produksi, sudah ditinggalkan. Tantangan dan era baru modal intelektual, human capital, asset non-tangible telah menggantikan era lama, organisasi perlu melakukan reengenering proces pengelolaan modal intelektual, mendorong kapasitas inovasi, membangun pola-pola baru, dan perhatian pada asset pengetahuan yang tidak kelihatan (intangible) dari para anggotanya dan jaringan koloborasi serta membangun hubungan organisasi

2. Menciptakan nilai melalui peningkatan pengetahuan dan ketrampilan karyawan. Karena pengetahuan dan keterampilan pekerja berasal dari pendidikan dan pelatihan, termasuk pelatihan yang membawa pengalaman yang menghasilkan nilai produktif (Baron dan Amstrong, 2007).

3. Dalam upaya creating value, pengelolaan manajemen sumber daya manusia merupakan katalisator yang mengaktifkan intangible capital, inert of tangible capital-material equipment dalam rangka memerbaiki efektivitas operasional.(Jac Fitz-enZ (2009). Karena factor manusia menentukan keberhasilan tujuan organisasi, maka perlu ditingkatkan mengenai intellectual capital (talent, knowledge, dan skill) dan relationship capital (hubungan dengan pelanggan, rekan, vendors dan stakeholders lainnya) (Burud dan Tumolo, 2004)

4. Mengembangkan nilai dengan membangun sistem untuk mencapai keunggulan kompetitif. Menurut Hall (2008) setidaknya ada tiga komponen yang perlu diperhatikan dalam upaya membangun sistem (building the system) untuk mencapai keunggulan kompetitif yaitu : efektivitas tim eksekutif, kinerja pemimpin, mengalahkan pesaing, dan kinerja karyawan. 
Digambarkan bahwa ada sistem yang dapat dikembangkan untuk memastikan bahwa orang-orang yang mereka miliki saat ini menjadi lebih berharga dibanding tahun yang lalu. Untuk itu diperlukan mendefinisikan kinerja, bagaimana menentukan kinerja kunci, dan bagaimana membangun sistem secara efektif untuk mengukur dan mengelola kinerja kunci tersebut.

5. Meningkatkan nilai human capital. Agar lebih bermanfaat untuk keunggulan daya saing organisasi, menurut Hall (2008), strategi peningkatan melalui pandangan bahwa manusia adalah satu-satunya sumber (resource) yang memiliki keunggulan kompetitif (competitive advantage). Bagaimana cara kita mengenalinya dan bagaimana kita mengukur dan mengelolanya, apa strategi kita, dan seberapa banyak human capital yang dimiliki, mampukah human capital tersebut ditingkatkan dari tahun ke tahun. Menurut Burud dan Tumolo (2004) strategi peningkatan human capital bukan sekedar mengingatkan perusahaan mencapai hasil lebih baik melalui orang seperti pada umumnya, melainkan cara ini dinilai sebagai sebuah strategi dalam mengelola SDM. Menerapkan strategi memuat :

a. Kekuatan kerja sebagai realitas baru, diyakini bahwa tujuan perusahaan bukan semata-mata mencari keuntungan, melainkan komitmen saling terbuka dalam suatu lingkungan kerja, sehingga mendorong adanya rasa tanggung jawab terhadap pekerjaan, saling membantu untuk memecahkan teknik dan keseimbangan kerja termasuk masalah kehidupan.

b. Faktor manusia menentukan keberhasilan tujuan organisasi, melalui penerapan intellectual capital (talent, knowledge, dan skill) dan relationship capital (hubungan dengan pelanggan, rekan, vendors dan stakeholders lainnya).

c. Manusia adalah unsur yang terpenting untuk mencari keunggulan kompetitif melalui kreativitas dan pengetahuan yang mereka miliki, hubungan mereka dengan customer, rekan kerja dan professional network.

d. Kekuatan strategi adaptif dalam meningkatkan human capital, terletak pada metode praktis beradaptasi yang mencakup : strategi berinvestasi melalui orang, strategi mengadopsi keyakinan baru, strategi memahami budaya oraganisasi, strategi metransformasi praktik manajemen dan strategi memastikan kesesuain antara keyakinan, budaya dan praktik. Ditambahkan oleh Amstrong (2012) bahwa melakukan investasi strategis dalam asset melalui keterlibatan karyawan, manajemen bakat, pembelajaran dan pengembangan program. Manajemen Human capital berkaitan dengan mendapatkan, menganalisis, dan melaporkan nilai tambah dari modal intelektual, serta pengelolaan human capital dengan menganggap karyawan sebagai asset untuk mencapai keunggulan kompetitif.

Modal intelektual sebagai asset yang dapat memenangkan persaingan jangka panjang, dapat memanfaatkan peluang dan antisipasi terhadap ancaman organisasi, karena sifatnya yang non fisik atau tak berwujud dalam realisasinya tentu akan banyak mendapati resistensi. Penolakan dapat dilakukan oleh individu, kelompok atau organisasi, penolakan dapat berbentuk eksplisit maupun implicit 
seperti; protes, mogok, demonstrasi, loyalitas berkurang, motivasi kerja menurun, absensi meningkat, dan lainnya.

Resistensi individual dapat timbul karena kebiasaan, rasa aman, faktor ekonomi, takut atas ketidak pastian, dan persepsi. Resistensi individual, kelompok atau organisasi di karena; inersia structural, focus perubahan berdampak luas, inersia kelompok kerja, ancaman terhadap keahlian, ancaman terhadap hubungan kekuasaan yang telah ada, hubungan terhadap alokasi sumber daya.

Untuk mengatasi penolakan individu maupun kelompok, Coch dan French Jr (2001) mengusulkan enam taktik:

1. Pendidikan dan komunikasi, yaitu memberikan penjelasan tentang latar belakang, tujuan, akibat dari diadakan perubahan.

2. Partisipasi, ajak semua berperan serta mengambil keputusan, pimpinan hanya sebagai fasilitator dan motivator.

3. Memberikan kemudahan dan dukungan.

4. Negosiasi dengan pihak-pihak yang resisten terhadap perubahan.

5. Manipulasi dan kooptasi, yakni menutupi kondisi yang sesungguhnya dengan yang lebih menarik, menyebarkan rumor dan lainnya.

6. Paksaan, berikan ancaman dan jatuhkan hukuman terhadap yang resisten.

\section{SIMPULAN}

Dewasa ini, studi empiris yang berkaitan dengan hubungan antara human capital dalam berbagai aspek dan kinerja perusahaan khususnya kinerja karyawan telah mengalami perkembangan yang demikian pesat. Baik secara teoritikal maupun empiris terdapat keterkaitan antara human capital dan kinerja karyawan, maka perusahaan sangat penting untuk melakukan pengelolaan terhadap SDM serta mendukung kinerja yang terbaik. Kinerja terbaik dari karyawan sangat penting bagi perusahaan untuk meningkatkan nilai perusahaan yang dapat memuaskan semua pihak, terutama stockholders.

Diharapkan, hasil penelitian ini dapat memberikan masukan bagi perusahaan dalam rangka mempersiapkan SDM yang lebih berkualitas dan meningkatkan kinerja karyawan sehingga kinerja perusahaan meningkat. Sudah saatnya para pemimpin perusahaan menyadari bahwa keuntungan yang diperoleh perusahaan sebenarnya berasal dari human capital, dan tidak melihat segala aktivitas perusahaan dari perspektif bisnis semata. Melainkan, lebih memandang perusahaannya sebagai sebuah unit yang berisi pengetahuan dan keterampilan yang unik atau seperangkat keunik. 


\section{DAFTAR PUSTAKA}

Ancok, D. 2008. Konsep Modal Manusia. http://ancok.staff.ugm.ac.id/h18/konsep-modal-manusia.html

Ancok, D.2002. Outbound Management Training: Aplikasi Ilmu Perilaku dalam Pengembangan Sumber Daya Manusia. Jogjakarta: UII Press.

Armstrong M . 2012, A Handbook of Human Resource Management Practice, published by Kogan Page Limited United Kingdom, 2012, hal. 29.

Arnold, Haugh J. and Daniel C. Feldman., (1986). Organizational Behavior. New York: McGraw-Hill Book Company.

Baron, Angela \& Armstrong, Michael. 2007. Human Capital Management, Kagon Page London and Philadelphia, 2007, hal. 6

Bechtel, R. (2007). Calculating human capital: The market based valuation of human capital. Zeitschrift Fur Personalforschung, 21(3), 206-231.

Bontis, N., \& Serenko, A. (2009). A causal model of human capital antecedents and consequences in the financial service industry. Journal of Intellectual Capital, 10(1), 391-401.

Bornemann, M., and K.H. Leitner.(2002). Measuring and reporting intellectual capital: the case of a research technology organisation, Singapore Management Review. Vol. 24 No. 3. pp.7-19.

Burr, R. and Girardi, A. 2002. "Intellectual Capital: More than the Interaction of Competence x Commitment" dalam Australian Journal of Management, Vol, 27.

Burud, Sandra and Marie Tumolo, Marie. 2004. LEVERANGING THE NEW HUMAN CAPITAL Adaptive Strategies, Result Achieved, and Stories of Transformation.

Carmeli, A., \& Tishler, A. (2004). Resource, capabilities and the performance of industrial firms: A multivariate analysis. Managerial and Decision Economics, 25, 299-315. Jurnal Kajian Manajemen Bisnis, Volume 3, Nomor 2, September 2014

Coch L \& JRP French JRP Jr. 2001. Overcoming Resis tance to Change; John Wiley \& Son, Inc,New York

Davemport, T.O. 1999. Human Capital: What It Is and Why People Invest In It. San Francisco: Jossey Bass.

Dian Swastari, analisis penerapan human capital management terhadap kinerja karyawan studi pada pt. telkomsel branch purwokerto.

Doddy Wahyu Triatmaja, 2016. pengaruh human capital terhadap kinerja pada karyawan unit simpan pinjam koperasi serba usaha (ksu) mekar surya karanganyar tahun 2016. Publikasi Ilmiah. FEB Universitas Muhammadiyah Surakarta.. 
Edvinsson, L., and Malone, M.S. (1997). "Intellectual Capital: Realizing Your Company"s True Value by founding it Hidden Brainpower. New York: Harper Business.

Eka Mulya Prasetya, Hamidah Nayati Utami, Arik Prasetya pengaruh human capital, information capital dan organizational capital terhadap kinerja karyawan (Studi Pada Karyawan PT PLN (Persero) Unit Induk Pembangunan VIII Surabaya). Jurnal Administrasi Bisnis (JAB)|Vol. 40 No.1 November 2016 administrasibisnis.studentjournal.ub.ac.id

Fitz-enz, J, 2000. The ROI of Human Capital: Measuring the Economic Value Added of Employee Performance, AMA-COM. New York: American Management Association,

Follis, E. (2001). Organization development \& human resources: Planning for the future. Organization Development Journal, 19(2), 37-46.

Fuji Utama. Peningkatan kinerja karyawan melalui Human capital dan Komitmen Organisasi Karyawan PT. Aspex Kumbong Bogor.

Gibson, James L., John M. Ivancevich, dan James H. Donnelly, Jr., 1997. Organization: Behavior, Structure and Process. Boston: Homewood, Richard D. Irwin.

Hall, Brandlet W. 2008. The New HUMAN CAPITAL STRATEGY Improving the Value of Your Most Importan Investment-Year After Year.

Hasibuan, Malayu S.P. 2008. Manajemen Sumber Daya Manusia. Edisi Revisi. PT.Bumi Aksara. Jakarta.

Hendrawan, Sanerya et al. 2012. Pengembangan Human Capital Perspektif Nasional, Regional, dan Global. Graha Ilmu. Yogyakarta.

Hitt, M. A., Bierman, L., Shimizu, K., \& Kochhar, R. (2001). Direct and moderating effects of human capital on strategy and performance in professional service firms: A resource based perspective. Academy of Management Journal, 44(1), 13-28.

Husen Sutisna, Aida Vitayala S.Hubeis, Muhammad Syamsu. 2014. Peran Human Capital, Corporate Value dan Good Corporate Governance melalui Kinerja Karyawan terhadap Kinerja Perusahaan di PTPN VII Lampung Manajemen IKM, September $2014 \quad$ (131-139). http://journal.ipb.ac.id/index.php/jurnalmpi/

Jac Fitz-enZ. 2009. HUMAN CAPITAL Measuring the Economic Value of Employee Performance

LAN, 1992. Penilaian Kinerja Pegawai, Jakarta: LAN.

Mathis, R. L., \& Jackson, J. H. (1999). Human resource management (9 ed.): South Western Educational Pub.

Mathis, Robert L. dan John H. Jakson. 2003. Human Resource Management, South-Western: Thomson Learning. 
Mayo, A. 2000. "The Role of Employee Development in The Growth of Intellectual Capital" dalam Personal Review, Vol. 29, No. 4.

Morling, M. S., and Yakhlef, A., 1999. The Intelectual Capital: Managing by Measure. New York: City University of New York, .

OECD (1999:12) OECD. (1999). “OECD Principles of Corporate Governance”.

Olaniyan, D.A dan T. Okemakinde. 2008. Human Capital Theory: Implications for Educational Development. Pakistan Journal of Social Sciences 5 (5): 479483.

Peter Rex Massingham, Leona Tam, (2015) "The relationship between human capital, value creation and employee reward", Journal of Intellectual Capital, Vol. 16 Issue: 2, pp.390-418, doi: 10.1108/ JIC-06-2014-0075 http://dx.doi.org/10.1108/JIC-06-2014-0075.

Ployhart, R.E. dan T.P. Moliterno. 2011. Emergence of the Human Capital Resource: A Multilevel Model. Academy of Management Review, 36: 127150.

Rachmawati, D., F. Wulani, dan C. E.Susilowati. (2004). Intellectual Capital dan Kinerja Bisnis: Studi Empiris padaIndustri di Indonesia. Seminar Internasional Management and Research Conference. Sanur Beach Bali Hotel, FE-Universitas Indonesia, Agustus: 1-21.

Rivai, Veithzal. 2004. Manajemen Sumber Daya Manusia Untuk Perusahaan : Dari Teori Ke Praktek. Edisi I. Cetakan I. PT.RajaGrafindo Persada. Jakarta.

Rivai, Veithzal. 2005. Performance Appraisal. Edisi Pertama. PT.RajaGravindo Persada. Jakarta.

Ross, Dragonetti, dan Edvinsson 2005. Roos, G., Pike, S., and Fernstrom, L. (2005). Ebook - Managing Intellectual Capital in Practice. Elsever Inc.

Sangkala (2006). Intellectual Capital Management: Strategi Baru Membangun Daya Saing Perusahaan. Edisi Pertama, Penerbit Ikatan Penerbit Indonesia DKI Jakarta. ISBN: 979-3274-29-8.

Sawarjuwono, T., dan A. P. Kadir. (2003). Intellectual Capital: Perlakuan, Pengukuran dan Pelaporan. Jurnal Akuntansi dan Keuangan Vol.5, No.1, Mei: $35-57$.

Schermerhon. (2005). Management, 8th edition. John Wiley \& Sons, Inc, USA

Schuler S dan Jackson S. 1999. Manajemen Sumber Daya Manusia. Edisi 6. Penerbit Erlangga. Jakarta

Schultz, Theodore W. 1961. Investment in Human Capital. American Economic Review. 51 (1): 1-17.

Sharabati, A.A., S.N. Jawad dan Bontis. 2010. Intellectual Capital and Business Performance in the Pharmaceutical Sector of JORDAN. Journal Management Decision. (48)1: 105-131. 
Simanjuntak, Payaman J. 2005. Manajemen dan Evaluasi Kerja. Lembaga Penerbit FEUI, Jakarta.

Steers, Richard M and Lyman W. Porter.,1987. Motivation and Work Behavior. New York : McGraw-Hill Book Company.

Sukarman Purba. 2019. Pengaruh Budaya Organisasi, Modal Intelektual dan Perilaku Inovatif terhadap Kinerja Pemimpin Jurusan di Universitas Negeri Medan. Jurnal : Kinerja, Volume 13, No.2, Th. 2009: Hal.150-167

Tangkilisan, H.N. (2005). Manajemen Publik. Jakarta: Gramedia Widia.

Totanan, C. 2004. Peranan Intellectual Capital dalam Penciptaan Nilai untuk Keunggulan Bersaing. Usahawan, No.1, Tahun XXXIII, Januari: 27-31.

Ulrich, Dave. 1997. Human Resource Champions, USA: Harvard Business School Press.

Usup, R. C. (2011). Pengaruh Human Capital, Structural Capital, Relational Capital Terhadap Kinerja Layanan Bank dan Kepuasan Pelanggan (Studi pada Industri Jasa Bank Umum di Kalteng). Disertasi. Program Doktor Ilmu Manajemen Fakultas Ekonomi \& Bisnis Universitas Brawijaya. Malang.

Wang, I.-M., \& Shieh, C.-J. (2008). Effect of human capital investment on organizational performance. Social Behavior and Personality, 36(8), 10111022.

Weatherly, L.A. 2003. "The Value of People: The Challenges and Opportunities of Human Capital Measurement and Reporting," dalam Research Quarterly. Society for Human Resource Management.

Wibowo, 2012. Manajemen Perubahan, Jakarta, PT Raja Grafindo

Wright, C., Moliterno. 2013. Strategic Human Capital: Crossing the Great Divide. Journal of Management. 20(10):1-18 doi: 10.1177/0149206313518437

Wright, P. M., McMahan, G. C., \& McWilliams, A. (1994). Human resource and sustained competitive advantage: A resource-based perspective. International Journal of Human Resource Management, 5(2), 301-326.

Wright, P.M., Dunford, B.B., \& Snell, S.A. 2001. "Human resources and the resource-based view of the frm" dalam Journal of Management, 27.

Yang, C., and Lin, C. (2009). Does intellectual capital mediate the relationship between HRM and organizational performance? Perspective of a healthcare industry in Taiwan. The International Journal of Human Resource Management, Vol. 20, No. 9, 1965-1984.

Zula, Kenneth J. dan Thomas J. Chermack. 2007. Human Capital Planning: A Review of Literature and Implications for Human Resource Development. Human Resource Development Review 6 (3): 245-262 